\title{
PECULIARITIES OF FREE RADICAL OXIDATION AND ANTIOXIDANT PROTECTION PARAMETERS OF THE ORAL FLUID IN CHILDREN WITH CHRONIC CATARRHAL GINGIVITIS WITH UNDERLYING DIABETES MELLITUS
}

DOI: 10.36740/WLek202104114

\author{
Liudmyla F. Kaskova', Valentyna A. Honcharenko², Oksana V. Klitynska ${ }^{3}$ \\ 'UKRAINIAN MEDICAL STOMATOLOGICAL ACADEMY, THE MINISTRY OF HEALTH OF UKRAINE, POLTAVA, UKRAINE \\ ${ }^{2}$ BUKOVINIAN STATE MEDICAL UNIVERSITY, THE MINISTRY OF HEALTH OF UKRAINE, CHERNIVTSI, UKRAINE \\ 3STATE HIGHER EDUCATIONAL ESTABLISHMENT OF UKRAINE «UZHHOROD NATIONAL UNIVERSITY», THE MINISTRY OF HEALTH OF UKRAINE, \\ UZHHOROD, UKRAINE
}

\begin{abstract}
The aim: Objective of the research was to study peculiarities of free radical oxidation and antioxidant protection parameters of the oral fluid in children with chronic catarrhal gingivitis with underlying diabetes mellitus.

Materials and methods: Oral fluid was examined in 105 children aged 12 including somatically healthy ones with intact periodontium and chronic catarrhal gingivitis, suffering from diabetes mellitus up to 5 years and more than 5 years with chronic catarrhal gingivitis. The parameters of lipid peroxide oxidation (level of diene conjugates, Malone dialdehyde) and antioxidant protection (activity of SOD and catalase, POM, whole protein; ceruloplasmin; HS-groups) of the oral fluid were determined.

Results: The results obtained are indicative of available probable difference in the examined parameters among children depending on their general state of health and periodontal tissue condition. The best parameters were found among somatically healthy children with intact periodontium. They deteriorated in children with chronic catarrhal gingivitis available irrespective of their general state of health. They reached the most critical level in children with diabetes mellitus lasting longer than 5 years.

Conclusions: The course of chronic catarrhal gingivitis in children, both somatically healthy and those suffering from diabetes mellitus, is associated with increased parameters of lipid peroxide oxidation and decreased enzymatic activity of the antioxidant protection system of the oral fluid. The most considerable changes are found in patients suffering from diabetes mellitus lasting more than 5 years.
\end{abstract}

KEY WORDS: lipid peroxide oxidation, antioxidant protection, oral fluid

Wiad Lek. 2021;74(4):887-890

\section{INTRODUCTION}

Current views concerning genesis of dental diseases are based on a considerable role of membrane-stabilizing processes and mechanisms realizing them. There is a great amount of scientific studies that present arguments concerning lipid oxidation constantly available in all the organs and tissues under physiological conditions in small amounts . Under certain conditions, due to high chemical activity, radicals react with the major biological compounds disturbing their structure and functions. The antioxidant body system controls and inhibits all the stages of free radical reactions beginning from their initiation till the formation of hydroperoxides and Malone dialdehyde. Failure of the antioxidant protective mechanisms promotes an increased level of lipid peroxide oxidation (LPO) products in the body, resulting in realization of a non-specific complex of damage of the cellular membranes. Proteins play an important role in metabolic processes. When the processes of lipid peroxide oxidation are intensified, protein modification processes occur resulting in their fragmentation, denaturation, loss of their biological activity leading to disorders of regenerative processes in the tissues $[1,2,3]$. The role of lipid peroxide oxidation processes and the antioxidant system state in the development of different diseases including diabetes mellitus is confirmed $[4,5]$. At the same time, intensification of protein oxidative modification (POM) and LPO, decrease of the antioxidant protection system activity of the oral fluid are found in case of inflammatory diseases of the periodontal tissue $[6,7,8]$.

\section{THE AIM}

Study peculiarities of free radical oxidation and antioxidant protection parameters of the oral fluid in children with chronic catarrhal gingivitis with underlying diabetes mellitus.

\section{MATERIALS AND METHODS}

To solve the task stomatological and laboratory examination of 105 children aged 12 was carried out. 65 children suffering from diabetes mellitus treated at the Children 
Table I. Parameters of lipid peroxide oxidation of the oral fluid of children in the groups of observation $(M \pm m)$

\begin{tabular}{|c|c|c|c|}
\hline \multirow[b]{2}{*}{ Groups, number of children } & \multicolumn{3}{|c|}{ Parameters of lipid peroxide oxidation $(M \pm m)$} \\
\hline & $\begin{array}{c}\text { POM } \\
\text { (nmol/mg of protein) }\end{array}$ & $\begin{array}{l}\text { Diene conjugate } \\
\text { (mcM/ml of saliva) }\end{array}$ & $\begin{array}{l}\text { Malone dialdehyde } \\
\text { ( } \mathrm{mcmol} / \mathrm{L})\end{array}$ \\
\hline Group $1(n=22)$ & $138,25 \pm 5,91$ & $5,18 \pm 1,45$ & $55,04 \pm 1,26$ \\
\hline Group $2(n=18)$ & $176,61 \pm 4,01$ & $8,47 \pm 0,93$ & $70,59 \pm 1,36$ \\
\hline $\mathrm{p}^{1}$ & $<0,05$ & $<0,05$ & $<0,05$ \\
\hline Group $3(n=35)$ & $202,57 \pm 2,35$ & $15,53 \pm 0,73$ & $91,68 \pm 1,19$ \\
\hline $\mathrm{p}^{2}$ & $<0,05$ & $<0,05$ & $<0,05$ \\
\hline $\mathrm{p}^{3}$ & $<0,05$ & $<0,05$ & $<0,05$ \\
\hline Group $4(n=30)$ & $215,22 \pm 1,35$ & $19,31 \pm 0,81$ & $103,59 \pm 1,10$ \\
\hline $\mathrm{p}^{4}$ & $<0,05$ & $<0,05$ & $<0,05$ \\
\hline $\mathrm{p}^{5}$ & $<0,05$ & $<0,05$ & $<0,05$ \\
\hline $\mathrm{p}^{6}$ & $>0,05$ & $>0,05$ & $>0,05$ \\
\hline
\end{tabular}

Notes:

$\mathrm{p}^{1}$ - difference probability of parameters in children of groups 1 and 2;

$\mathrm{p}^{2}$ - difference probability of parameters in children of groups 1 and 3 ;

$\mathrm{p}^{3}$ - difference probability of parameters in children of groups 2 and 3 ;

$\mathrm{p}^{4}$ - difference probability of parameters in children of groups 1 and 4 ;

$p^{5}$ - difference probability of parameters in children of groups 2 and 4 ;

$p^{6}$ - difference probability of parameters in children of groups 3 and 4.

Table II. Parameters of the antioxidant protection of the oral fluid among children from the groups of observation $(M \pm m)$

\begin{tabular}{cccccc}
\hline $\begin{array}{c}\text { Groups of children, } \\
\text { number }\end{array}$ & $\begin{array}{c}\text { Whole protein } \\
\text { (g/L) }\end{array}$ & $\begin{array}{c}\text { SOD (UN/min* } \\
\text { mg of protein) }\end{array}$ & $\begin{array}{c}\text { HS-groups (pM/ } \\
\text { mg of protein) }\end{array}$ & $\begin{array}{c}\text { Ceruloplasmin } \\
\text { (mg/L) }\end{array}$ & $\begin{array}{c}\text { Catalase (nmol/ min* } \\
\text { mg of protein) }\end{array}$ \\
\hline Group 1 (22) & $3,26 \pm 0,43$ & $10,53 \pm 0,52$ & $120,29 \pm 4,03$ & $132,36 \pm 3,94$ & $6,69 \pm 1,15$ \\
\hline Group 2 (18) & $8,23 \pm 0,91$ & $7,36 \pm 0,11$ & $85,98 \pm 1,69$ & $106,99 \pm 4,19$ & $4,71 \pm 0,56$ \\
\hline$p^{1}$ & $<0,05$ & $<0,05$ & $<0,05$ & $<0,05$ & $<0,05$ \\
\hline Group 3 (35) & $14,58 \pm 0,13$ & $5,03 \pm 0,13$ & $67,59 \pm 0,76$ & $91,3 \pm 3,77$ & $<, 31 \pm 0,03$ \\
\hline$p^{2}$ & $<0,05$ & $<0,05$ & $<0,05$ & $<0,05$ & $<0,05$ \\
\hline$p^{3}$ & $<0,05$ & $<0,05$ & $<0,05$ & $<0,05$ & $<0,05$ \\
\hline Group 4 (30) & $17,26 \pm 0,09$ & $4,42 \pm 0,05$ & $56,68 \pm 0,82$ & $79,85 \pm 3,03$ & $1,75 \pm 0,02$ \\
\hline$p^{4}$ & $<0,05$ & $<0,05$ & $<0,05$ & $<0,05$ & $<0,05$ \\
\hline$p^{5}$ & $<0,05$ & $<0,05$ & $<0,05$ & $<0,05$ & $>0,05$ \\
\hline$p^{6}$ & $>0,05$ & $>0,05$ & $>0,05$ & $<0,05$ \\
\hline
\end{tabular}

Notes:

$\mathrm{p}^{1}$ - difference probability of parameters in children of groups 1 and 2;

$p^{2}$ - difference probability of parameters in children of groups 1 and 3;

$\mathrm{p}^{3}$ - difference probability of parameters in children of groups 2 and 3;

$\mathrm{p}^{4}$ - difference probability of parameters in children of groups 1 and 4;

$p^{5}$ - difference probability of parameters in children of groups 2 and 4;

$\mathrm{p}^{6}$ - difference probability of parameters in children of groups 3 and 4.

Endocrinological Department of the Municipal Institution "Regional Children Clinical Hospital" were examined including 35 individuals with diabetes lasting up to 5 years (group 3), and 30 ones with diabetes lasting longer than 5 years (group 4). The groups of comparison consisted of children without underlying pathology with healthy periodontium (22 individuals - group1) and with chronic catarrhal gingivitis (18 individuals - group 2).
Oral fluid of children from the groups of observation was the material for additional examination. Oral fluid of children for paraclinical examination was collected in the morning after rinsing the oral cavity twice with distilled water. The material was obtained by means of spitting out without stimulation of salivation in the volume of 5-6 ml. The material was transported and stored at $-5^{\circ} \mathrm{C}$. Before biochemical analyses the oral fluid was centrifuged during 
15 minutes at a speed of $3000 \mathrm{rpm}$. Supernatant was used for examination. The following parameters were determined: the level of diene conjugates, Malone dialdehyde by N.D. Stalna's method [1977]; catalase activity with the use of ammonia molybdate [ M.A. Koroliuk,1988]; SOD activity by S.Chevari's method [1985]; POM degree was assessed by the principle of interaction of amino acid protein residues with 2,4-dinitrophenylhydrazine with the formation of derivatives [E.E.Dubynina, S.O. Burmistrov,1995] in modification [I.F. Meshchyshen,1998]; whole protein; ceruloplasmin; HS-group.

The results obtained were statistically processed by Student method. The results with $\mathrm{p} \leq 0,05$ were considered reliable.

\section{RESULTS AND DISCUSSION}

The parameters of lipid peroxide oxidation of the oral fluid of children from the groups examined possessed a reliable difference depending on the general health state and periodontal tissue condition (Table I). The best parameters were observed among somatically healthy children and intact periodontium. The worst parameters were found in children with chronic catarrhal gingivitis and diabetes mellitus lasting longer than 5 years.

Somatically healthy children with underlying diabetes mellitus and chronic catarrhal gingivitis present activation of the protein oxidative modification processes of the oral fluid in comparison with children having healthy periodontal tissue. POM degree of the oral fluid depends on the availability and duration of the underlying disease (diabetes mellitus) and periodontal tissue diseases available. The highest parameter was found among children suffering from diabetes mellitus longer than 5 years and have chronic catarrhal gingivitis. Protein oxidative modification degree in children from group 1 is by 1,28 times lower than in children from group 2. Thus, the course of chronic catarrhal gingivitis in somatically healthy children occurs together with deterioration of the parameter $(p<0,05)$. The parameter increases in children suffering from diabetes mellitus lasting up to 5 years (by 1,15 times) and those with the duration of more than 5 years (by 1,22 times). A probable difference among the examined parameters depending on the duration of the underlying disease was not found, though numerical values differed.

The concentration of diene conjugates was the highest in patients with chronic catarrhal gingivitis and duration of diabetes mellitus of more than 5 years. In comparison with somatically and stomatologically healthy children this parameter 3,73 times increased $(5,18 \pm 1,45 \mathrm{mcM} / \mathrm{ml}$ - in group 1 against 19,31 $\pm 0,81 \mathrm{mcM} / \mathrm{ml}$ - in group 4). A similar tendency was found concerning Malone dialdehyde as well. The numerical values deteriorate in children with chronic catarrhal gingivitis, and it becomes of a maximum value in patients with inflammatory processes in the periodontal tissue and diabetes mellitus lasting for more than 5 years.

The antioxidant protection system functioning regulates free radical processes in the cells and tissues promoting ensuring free radical homeostasis in the whole body and oral cavity in particular. Examination of the parameters of antioxidant protection of the oral fluid in children from the groups of observation found their difference (Table II). The whole protein parameter is of a special attention, since it 5,3 times increases among the patients from group 4 in comparison with group 1 , and the parameter of catalase activity 3,8 times decreases $\left(6,69 \pm 1,15 \mathrm{nmol} / \mathrm{min}^{\star} \mathrm{mg}\right.$ of protein - in group 1 against $1,75 \pm 0,02$ in group 4$)$. Hydrogen peroxide is utilized by the intracellular iron-containing enzyme catalase which is functioning in a close relation with SOD. Therefore, examination of this parameter is important. Our studies found its decrease among the patients from groups 2,3 and 4 in comparison with healthy children (group 1). The worst parameter was found in children from group 4. It was 2,4 times lower than that of children from group 1. A probable difference of superoxide dismutase enzyme activity in children with different duration of diabetes mellitus was not found, but the parameters were worse in patients suffering from diabetes mellitus more than 5 years $\left(5,03 \pm 0,13 \mathrm{UN} / \mathrm{min}^{\star} \mathrm{mg}\right.$ of protein in group 3 against $4,42 \pm 0,05$ - in group 4$)$.

The parameters of activity of HS-groups and ceruloplasmin decrease in case of inflammatory processes in the periodontal tissue, especially among children suffering from diabetes mellitus longer than 5 years.

A probable difference of $\mathrm{POM}$, diene conjugates, Malone dialdehyde, whole protein, HS-group, ceruloplasmin, SOD activity, catalase of the oral fluid of children was found among different groups of observation. The highest rates were observed in children with a history of diabetes and suffering from it for more than 5 years. Increase of lipid peroxide oxidation parameters and decrease of enzymatic activity of the antioxidant protective system of the oral fluid were found in children with chronic catarrhal gingivitis available. The most considerable changes are found in patients with diabetes mellitus lasting for more than 5 years. Thus, the processes of antioxidant protection in children are influenced by the presence of somatic pathology and its duration, which is confirmed by the literature $[2,6]$.

\section{CONCLUSIONS}

The results obtained force to regulate the processes of antioxidant protection in children with chronic catarrhal gingivitis especially with diabetes mellitus by means of development of therapeutic complexes which is a subject of further studies.

\section{REFERENCES}

1. Hnatiuk V.V. Gender and Age Peculiarities of Free Radical Oxidation and Antioxidant Protection with desynchronosis. Bulletin of Vinnytsia National Medical University. 2014; 2: 363-6.

2. Hovorukha 0.Yu. The Value of Interaction of Lipid Peroxide Oxidation and Antioxidant Systems in the Development of Pathological Processes. Experimental and Clinical Medicine. 2016; 4 (73):10-14.

3. Tiazhka 0.V. The State of Lipid Peroxide Oxidation and Antioxidant System in Children of Different Age. Perinatology and Pediatrics. 2016; 2(66): 101-5. 
4. Mokryi V.Ya. Disorders of the Lipid Peroxide Oxidation System with Type 2 Diabetes Mellitus (literature review). International Journal of Endocrinology. 2015; 7(71):41-4.

5. Maydannyk V.H. The State of Lipid Peroxide Oxidation and Antioxidant System in Children Suffering from type 1 Diabetes Mellitus Depending on Chronic Complications Available .Issues of Clinical Pediatrics. 2018; 4(42): 26-8.

6. Palasiuk B.0. Lipid Peroxide 0xidation and Protein Oxidative Modification in the Oral Fluid of Preteen Schoolchildren with Chronic Catarrhal Gingivitis. Topical Issues of Modern Medicine. 2012; 4 (40):50-4.

7. Yanko N.V. The Mechanisms of Disorders of Free Radical Processes in the Periodontal Tissue of Rats under Conditions of Experimental Periodontitis and Development of Methods to Correct Them. Wiadomosci Lekarskie. 2016;3: 521-3.

8. Kaskova L.F. The Parameters of Calcium, Inorganic Phosphorus and Antioxidant Status of the Oral Fluid in Children with Chronic Catarrhal Gingivitis during the Period of Transitional Dentition. World of Medicine and Biology. 2013;1(36):187-8.

9. Ullah A., Khan A., Khan I. Diabetes mellitus and oxidative stress - a concise review. Saudi Pharm J. 2016;24(5):547-53.

10. Hodovanets 0.I., Kotelban A.V. Osoblyvosti perebihu khronichnoho kataralnoho hinhivitu v ditei za umov tsukrovoho diabetu. Visnyk stomatolohii. 2016; 4: 60-5. (In Ukrainian).
"Improvement of methods of prevention and treatment of diseases of hard tissues of teeth and periodontal tissues on the background of somatic pathology in children, taking into account socio-economic factors and psycho-emotional state» (0119U102852).

\section{ORCID and contributionship:}

Lyudmyla F. Kaskova: 0000-0003-0855-2865 A,F

Valentyna A. Honcharenko: 0000-0001-7276-9052 B,D

Oksana V. Klitynska: 0000-0001-9969-2833 ${ }^{C, E}$

\section{Conflicts of interest:}

The Authors declare no conflicts of interest.

\section{CORRESPONDING AUTHOR Valentyna A. Honcharenko \\ Bukovinian state medical university \\ 2 Teatralna square, 58000 Chernivtsi, Ukraine \\ tel: +380677176001 \\ e-mail:V.honcharenko_84@meta.ua}

Received: 10.11 .2020

Accepted: 01.03.2021

A - Work concept and design, B - Data collection and analysis, $\mathbf{C}$ - Responsibility for statistical analysis,

D-Writing the article, $\mathbf{E}$-Critical review, $\mathbf{F}$ - Final approval of the article 